\title{
Käsityöaktivismi osallistaa ja aktivoi ajattelemaan
}

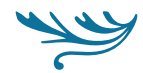

\author{
Käsityöaktivismi yhdistää aktivismin ja kädentaidot. \\ Matalan kynnyksen osallistamisen menetelmällä \\ herätetään yhteiskunnallista keskustelua.
}

KÄSITYÖAKTIVISMI ON VIELÄ SUOMESSA kohtalaisen marginaalinen ilmiö. Toistaiseksi vain pieni joukko opettajia, käsityöharrastajia ja aktivisteja on tekstiilitaiteilijoiden lisäksi ottanut käsityöaktivismin käsitteen haltuunsa. Yksi osallistavan ja aktivoivan käsityö- ja kulttuuriaktivismin omaksuneita on KSLopintokeskus, jonka toimintaa pitää yllä Kansan Sivistystyön Liitto (KSL).

KSL-opintokeskus on valtakunnallinen vapaan sivistystyön oppilaitos, joka tukee kansalaisten elinikäistä oppimista ja edistää kansanvaltaisuuden ja tasa-arvon toteutumista yhteiskunnassa. Kantavana ajatuksena on, että jokaisella on oikeus oppia ja jokaista opiskelijaa halutaan tukea aktiiviseen kansalaisuuteen. KSL-opintokeskuksessa uskotaan, että käsityöaktivismi toimintamuotona toteuttaa hyvin sen tavoitteita vapaan sivistystyön toimijana.

\section{KÄSITYÖ JA AKTIVISMI YHDISTYVÄT}

'Käsityöaktivismilla' ei tarkoiteta aktiivista ja ahkeraa käsitöiden tekemistä. Käsitteellä viitataan muutosta tavoittelevaan kansalaisaktivismiin, jonka ilmaisumuotona toimii käsityö. Käsityöaktivismi on aktiivista toimintaa, jossa tehdään sekä käsillä että pyritään muuttamaan epäoikeudenmukaiseksi koettuja yhteiskunnan käytäntöjä. Suomessa on toisinaan käytetty myös termejä kraftivismi ja craftivismi, mutta 'käsityöaktivismi' on edellisiä kuvaavampi ja istuu luontevammin kielenkäyttöömme.

Suomessa 'käsityö' on usein tulkittu niin tutkijoiden määritelmissä kuin arkikielessä kahtiajakoisena. Sillä tarkoitetaan sekä käsillä työskentelyä että työskentelyn tulosta, käsityötuotetta. Siten 'käsityöllä’ voidaan viitata aineettomaan käsityöprosessiin 


\section{YHTEISKUNNALLISEN}

AKTIIVISUUDEN ILMAISUMUODOT

LAAJENEVAT KÄSITYÖ-

AKTIVISMIN SUUNTAAN.

tai materiaaliseen lopputuotteeseen (esim. Anttila, 1983, 37; Suojanen, 1993, 13). Vaikka käsityöhön kuuluu olennaisena materiaalisuus, se voidaan nähdä myös kulttuurisena ilmiönä. On esitetty, että käsityö on yksi tapa olla sosiaalinen: tapa tulkita, luoda ja kohdata kulttuuria sekä muita ihmisiä. (Kouhia \& Laamanen 2014, 13.)

Aktivismi voidaan määritellä suoran toiminnan politiikaksi, jossa yhteiskunnassa epäoikeudenmukaiseksi koettuja käytäntöjä yritetään muuttaa aktiivisella kansalaistoiminnalla. Perinteisiä kansalaisaktivismin ilmenemismuotoja ovat mielenosoitukset ja marssit, julkisten vetoomusten kirjoittaminen, nimien kerääminen adresseihin tai boikotointi. (Martin 2007.)

Aktivismista puhuttaessa nousee usein esiin ajatus, että aktivismilla halutaan lisätä ihmisten tietoisuutta vallitsevan yhteiskunnan epäkohdista. Vaikka tietoisuuden lisääminen kuuluu olennaisena aktivismiin, on myös esitetty, että se ei yksinään riitä. Tehokkaan aktivismin tavoitteena on jonkin yhteiskunnallisen epäkohdan poistaminen tai vähintään ihmisten herättäminen ajattelemaan, miksi jonkin epäkohdan esiintyminen yhteiskunnassa on edes mahdollista. Ei siis riitä, että epäkohtaa tarkastellaan passiivisesti, vaan aktivismilla pyritään aktivoimaan katsojia. (Corbett 2017, 15.)

Kun yhteiskunnallisen aktiivisuuden ilmaisumuotojen mahdollisuudet laajenevat käsityöaktivismin suuntaan, järjestöjen ja yhteiskunnallisten liikkeiden on mahdollista saada uusia jäseniä ja löytää uusia toimintamuotoja. Vapaan sivistystyön toimijoiden koulutus- ja kulttuuritoiminta voi olla tässä merkittävä tuki muille kansalaisyhteiskunnan toimijoille.

Vaikka materiaalisiin käsityötuotteisiin liitetään usein mielikuvia hyvästä laadusta, käsityön ei tarvitse täyttää tarkkoja tai yksiselitteisiä laadun kriteereitä ollakseen käsityötä (Kouhia \& Laamanen 2014, 13; 18). Aloittelijan valmistamaa tuotetta voidaan pitää käsityönä siinä missä ammattikäsityöläisen tai kokeneen harrastajan tekemää käsityötä.

Käsityöaktivismi voisi tarjota vapaan sivistystyön oppilaitoksille mahdollisuuden houkutella käsityökursseille kokeneiden harrastajien rinnalle aloittelijoita, joille käsillä tekemisen lisäksi on tärkeää yhteiskunnallinen keskustelu ja omien ajatusten ilmaisu. Yhtä lailla perinteisiin käsityökursseihin voidaan sisällyttää yhteiskunnallista näkökulmaa, jolloin vapaan sivistystyön lain velvoite aktiivisten kansalaisten kasvattamisesta on luonteva osa toimintaa.

Aktivismityöpajoissa olen törmännyt ajatukseen, että kaikenlainen käsitöiden tekeminen itsessään on käsityöaktivismia, koska käsityötä pidetään kapitalismin ja teollisesti massatuotettujen tekstiilituotteiden vastavoimana. Harrastuskäsityön ei kuitenkaan varsinaisesti voida ajatella tavoittelevan suurta yhteiskunnallista muutosta, vaikka yksilöiden näkökulmasta se voi vaikuttaa myönteisesti muun muassa mielenterveyteen. Esimerkiksi kansalaisopistoissa käsityökurssit ovat perinteisesti yksi suosituimpia ainealoja, mutta kursseilla keskitytään usein käsillä tekemiseen, eikä käsitöihin varsinaisesti yhdistetä yhteiskunnallista näkökulmaa.

Käsityöaktivismiin voidaan läheisesti liittää kriittisen pedagogiikan ajatuksia. Tämä onkin yksi syy, miksi KSL-opintokeskuksessa on haluttu lähteä osallistamaan ja aktivoimaan ihmisiä juuri käsityöaktivismin avulla.

Kriittinen pedagogiikka ei ole yksi selkeästi määriteltävissä oleva kasvatustieteellinen suuntaus eikä se muodosta yhtä määriteltävissä olevaa teoriakokonaisuutta. Yhteiskunnan ilmiöiden ymmärtämisen ohella siinä on keskeistä pyrkimys lisätä vähäosaisten toimintakykyä ja halu vähentää yhteiskunnan epätasa-arvoisuutta ja epäoikeudenmukaisuutta (Giroux \& McLaren 2001, 30).

Käsityöaktivismissa pyritään aktivoimaan ihmisiä osallistamalla heitä käsillä toteutettavaan toimintaan ja samalla pohtimaan yhteiskunnallisia asioita. Lisäksi siinä pyritään lopputuotoksen, käsityötuotteen, kautta aktivoimaan edelleen teoksen katsojia, joten 


\section{K̈̈SITYÖAKTIVISMISSA \\ ON OLENNAISTA}

VUOROVAIKUTUS.

vaikuttava kokemus ei jää pelkästään tekijöiden ja ohjaajan väliseksi. Resurssien, kuten materiaalien tai taitojen, puutteen ei pitäisi olla osallistumisen esteenä. Esimerkiksi lankoja ja neuloja on kaikkien halukkaiden saatavilla, joten käsityöaktivismia voidaan pitää lähtökohtaisesti matalan kynnyksen toimintana. Kuka tahansa ikään, sukupuoleen, taitoihin tai varallisuuteen katsomatta voi periaatteessa olla käsityöaktivisti. Käsityöaktivismia voidaan toteuttaa yksin tai yhdessä muiden ihmisten kanssa.

\section{KÄSILLÄ LUOMINEN AUTTAA YMMÄRTÄMÄÄN DEMOKRATIAA}

Käsityöaktivismin termin (craftivism) lanseerasi oletetusti ensimmäisen kerran vuonna 2003 yhdysvaltalainen sosiologi ja käsityöharrastaja Betsy Greer. Vuoden 2000 presidentinvaalien edellä hän oli nähnyt halloween-paraatissa ehdokkaita esittäviä suuria nukkehahmoja. Äänettöminä edenneet ja taidokkaana käsityönä valmistetut nuket olivat saaneet vaalitilanteesta huolestuneet kulkueen seuraajat yllättäen hiljentymään, vaikka muuten äänekäs paraati levitti iloista hälinää ympärilleen. Ristiriitainen reaktio sai Greerin pohtimaan, voisiko hiljaisen käsityön keinoin pyrkiä vaikuttamaan yhteiskunnan epäkohtiin. Vuonna 2002 hän kirjoitti, että käsillä luominen auttoi ymmärtämään demokratiaa paremmin, koska se muistutti ihmisiä siitä, että heillä voi olla vaikutusvaltaa.

Greer on korostanut, että käsityöaktivismissa ovat olennaisia vuorovaikutus ja dialogi niistä epäoikeudenmukaiseksi koetuista asioista, joihin käsitöillä pyritään ottamaan kantaa. Vaikka Greer on esittänyt, että käsityöaktivismi on hiljaista aktivismia, hän viittaa hiljaisuudella pikemmin materiaaliseen käsityötuotteeseen kuin aineettomaan käsityöprosessiin. Vuonna 2003 Greer alkoi pitää käsityöaktivismille omistettua verkkosivustoa, jonka kautta ilmiö levisi hiljalleen laajempaan tietoisuuteen ympäri maailmaa. (Greer 2014, 7-8.)

Omissa kirjoituksissaan Greer ei ole halunnut määritellä tarkasti, mitä käsityöaktivismi on. Hän on esittänyt, että toiminnalle ei ole varsinaisia sääntöjä. Viime vuosina käsityöaktivismia on pyrkinyt tarkemmin määrittelemään ja tekemään tutuksi laajemmalle yleisölle brittiaktivisti Sarah Corbett, joka on luennoinut Suomessakin. Hän kasvoi 1980-luvulla aktivistiperheessä ja tutustui yhteiskunnalliseen vaikuttamiseen jo lapsuudessaan. Vuonna 2008 Corbett koki väsyneensä perinteiseen aktivismiin ja alkoi kyseenalaistaa sen vaikutusmahdollisuuksia ja -keinoja. Hän ryhtyi tekemään pieniä kirjontatöitä, joihin hän kirjoi ristipistoin yhteiskunnallisia viestejä. Corbett tutustui Greerin kirjoituksiin käsityöaktivismista ja perusti seuraajiensa kanssa vuonna 2009 käsityöaktivismikollektiivin, joka levittää tietoisuutta käsityöaktivismista. (Corbett 2013, 3; Corbett 2017,2-3.)

Vaikka Greeriä ja Corbettia voidaan pitää nykyaikaisen käsityöaktivismin edelläkävijöinä, historiasta löytää niin todellisia kuin fiktiivisiäkin esimerkkejä käsityöaktivismista paljon ennen heidän aikaansa. Esimerkiksi Ranskan vallankumouksen aikaan 1700-luvun lopulla oli naisaktivisteja, jotka istuivat giljotiinin vieressä neulomassa sukkia ja symbolisia punaisia fryygialaismyssyjä. Heitä kutsuttiin termillä la tricoteuse, neuloja.

Kirjailija Charles Dickens kuvasi Kaksi kaupunkia -teoksessaan (1859) Ranskan vallankumouksen jälkeistä aikaa. Yksi teoksen henkilöhahmoista on la tricoteuse Madame Defarge, joka erilaisilla silmukoilla kirjoittaa neuleisiinsa niiden henkilöiden nimiä, jotka tulisi seuraavaksi teloittaa. Ilmiö ei jäänyt Suomessakaan huomiotta, kun runoilija Eino Leino runossa La Tricoteuse (1902) viittasi samaisiin kohtalokkaisiin neulojiin.

Käsityöaktivismin piirteitä voidaan nähdä myös 1900-luvun alussa Isossa-Britanniassa toimineiden, naisten äänioikeutta vaatineiden suffragettien toiminnassa. Naisaktivistit valmistivat käsityönä banderolleja ja pieniä asusteita, joissa toistuivat liikkeen tunnusvärit: purppuranpunainen kuvasti vapautta, valkoinen puhtautta ja vihreä toivoa. (Corbett 2017, 8.) 
Suomessakin käsityöllinen toiminta on ollut osana yhteiskunnallisesti merkittävää järjestötoimintaa, joka lisääntyi etenkin 1800-luvulla, kun työväestön sivistämiseen alettiin kiinnittää huomiota teollistumisen myötä. Esimerkiksi Marttayhdistys aloitti toimintansa vuonna 1899 Sivistystä kodeille -nimisenä vastatoimena helmikuun manifestille, jolla pyrittiin Suomen venäläistämiseen. Käsitöiden opettaminen naisille oli alusta alkaen keskeinen osa Marttayhdistyksen toimintaa. Sivistyneistön rouvien järjestämän toiminnan yhtenä pyrkimyksenä oli ohjata työläisnaisia käyttäytymään ja elämään tietynlaista, hyväksi katsottua elämää. Ajan myötä Marttayhdistyksen aktiivitoimijoiksi alkoi kuitenkin tulla kaikkien yhteiskuntaluokkien edustajia, ja holhoava ote jäi taka-alalle. (Ollila 1993, 25-31; Piesanen 2010.)

1900-luvulta esimerkkejä käsityöaktivismista on eri puolilta maailmaa. Esimerkiksi diktaattori Augusto Pinochetin valtakaudella 1970-80-luvuilla Chilessä ihmisoikeuksia rikottiin räikeästi, eivätkä kansalaiset uskaltaneet avoimesti osoittaa mieltään tai näyttää mielipiteitään. Chileläisnaiset alkoivat kirjailla näennäisen iloisiin ja värikkäisiin arpillerasperinnetekstiileihinsä salaisia viestejä, joilla he viestivät yhteiskunnan todellisesta tilasta. Yhteisöllinen käsitöiden tekeminen toisaalta yhdisti tekijöitä ja auttoi selviytymään mutta lisäsi samalla naisten yhteiskunnallista tietoisuutta ja poliittista aktiivisuutta. (Corbett 2017, 8; Greer 2014, 133-136.)

Latinalaisessa Amerikassa käsityöaktivismia on esiintynyt 2000-luvulla myös Meksikon huumesodan yhteydessä. Huumekartellien ja asevoimien välisissä yhteenotoissa on kuollut ja kadonnut kymmeniä tuhansia meksikolaisia. Vuonna 2011 aktivistiryhmittymä Bordados por la Paz, "kirjontaa rauhan puolesta”, aloitti käsityöaktivismihankkeen, jossa huumesodan uhreja muistetaan kirjomalla kankaalle heidän tarinoitaan (DalyGoggin 2014). Joka sunnuntai joukko käsityöaktivisteja kokoontuu yhä Mexico Cityssä julkiseen tilaan, torille, kirjomaan tarinoita, joissa punainen lanka kuvastaa uhrin kuolemaa, purppuranvärinen lanka uhrin joutumista seksuaalirikoksen uhriksi ja vihreä lanka sitä, että vielä on toivoa uhrin löytymisestä elossa (Amnesty 2017).
Yhdysvalloissa yksi kuuluisimpia käsityöaktivismiprojekteja on aids-muistotilkkutäkki. Siinä on yli 48000 kangaspalaa, joissa kunnioitetaan ja muistetaan tekstien ja kuvien avulla immuunikatoon menehtyneitä. Valtavan tilkkutäkin kokoaminen aloitettiin 1980-lopulla, kun aids alkoi rajusti levitä etenkin seksuaalivähemmistöjen keskuudessa. Tilkkutyöllä oli tarkoitus sekä muistaa menehtyneitä että lisätä tietoisuutta ja valistaa ihmisiä yhteiskunnallisesti merkittävästä sairaudesta ja siten estää sen leviäminen. Muistotilkkutäkki oli ehdokkaana Nobelin rauhanpalkinnon saajaksi vuonna 1989. Yhä kasvavaa tilkkutyötä on kutsuttu maailman suurimmaksi yhteisötaideteokseksi. (Greer 2014, 125131; The AIDS Memorial Quilt 2017.)

\section{MODERNI KÄSITYÖAKTIVISMI VIRIÄÄ SUOMESSA}

Viime vuosina Suomessa käsityöaktivismia ovat KSLopintokeskuksen lisäksi toteuttaneet tempausten ja työpajojen kautta muutamat ammattitaiteilijoiden ryhmittymät, kuten Softartivistit tai Concreatives.

Tammikuussa 2017 käsityökulttuurin edistämiseen keskittynyt Taitoliitto toteutti yhdessä Designmuseon kanssa "Sano se käsin" -teosreitin, jossa 22 käsityön, taiteen ja muotoilun ammattilaista laativat kantaa ottavia taideteoksia. Niistä muodostetiin näyttelyn tavoin läpi kuljettava reitti Helsingin keskustaan (Designmuseo 2017). Jotkin teokset edustivat selkeästi kantaaottavaa käsityöaktivismia, toisissa aktivismi sinänsä vaikutti olevan sivuosassa, ja taiteilijat keskittyivät pikemminkin visuaalisen elämyksen tuottamiseen.

Muutokseen pyrkivä käsityöaktivismi olisi pystyttävä erottamaan puhtaasti esittävästä taiteesta. Taiteen yhteiskunnalliseksi tehtäväksi on esitetty sitä, että se auttaa ihmisiä näkemään maailmaa erilaisin tavoin (Venkula 2003, 55). Käsityöaktivismi eroaa siten taiteesta siinä, että epäkohtien näkemisen lisäksi se saa ihmiset aktivoitumaan, ajattelemaan ja parhaimmillaan toimimaan yhä paremman yhteiskunnan tavoittelemiseksi.

Käsityöaktivismia on viime vuosina esiintynyt pienissä määrin käsityöharrastajien ja aktiivisten kansalaisten toteuttamana. Tällaista käsityöaktivismia 
edustavat satunnaisesti kokoontuvat kollektiivit, kuten eettisestä tekstiilialasta, pukeutumisesta ja muodista kiinnostunut Korjaussarjakollektiivi, sekä rohkeita ja radikaaleja ajatuksia ristipistoin toteuttava Radikaalit ristipistot-ryhmittymä (Korjaussarjakollektiivi; Utopia Helsinki 2017). Feminististä käsityöaktivismia edustavat Ajatushautomo Hatun järjestämät Vitun virkkaus -työpajat, joissa on kyseenalaistettu naisen asemaa ja käsityöharrastusta koskevia ennakkoluuloja (Feministinen ajatushautomo Hattu). Suomessa käsityöaktivismi on kuitenkin vielä niin pieni ilmiö, että itseään käsityöaktivisteiksi kutsuvia tekijöitä on vain kourallinen.

KSL-opintokeskus on pyrkinyt tekemään käsityöaktivismista helposti lähestyttävää toimintaa, johon kuka tahansa voisi osallistua ilman ennakkotietoja tai -taitoja. Sen toteuttama käsityöaktivismi on siten lähempänä harrastajien ja aktivistien toimintaa kuin ammattitaiteilijoiden projekteja. KSL-opintokeskus painottaa käsityöaktivismissaan yhteisöllisyyttä ja sitä, että käsityön keinoin tuotettu sanoma saa olla selkeästi radikaali ja kantaaottava. Käsityöaktivismilla innostetaan ihmisiä ottamaan osaa yhteiskunnalliseen keskusteluun ja kannustetaan niitä, jotka eivät koe perinteisiä aktivismin keinoja omikseen tai saa ääntään kuuluviin yhteiskunnassa. Jo aktivisteiksi itsensä kokeville käsityöaktivismi on uudenlainen keino tuoda omaa viestiä esiin.

\section{HUUDA HUOVUTTAMALLA HAKI MUUTOSTA}

KSL-opintokeskus aloitti käsityöaktivismitoiminnan kesällä 2016 järjestämällä ”Huuda huovuttamalla” -työpajan. Siihen ilmoittautui 15 käsitöistä, taiteesta ja yhteiskunnallisista asioista kiinnostunutta. Taustalla oli ajatus siitä, että muutkin kuin ammattitaiteilijat voisivat käyttää taidetta yhteiskunnallisena keskustelumuotona. Kolmen päivän aikana osallistujat toteuttivat yksin tai yhdessä vapaavalintaisella tekniikalla kantaaottavan tekstiilitaideteoksen teemalla "Huuda muutos yhteiskuntaan".

Työpajassa syntyi 12 teosta, joissa käsiteltiin muun muassa ihmisoikeuksia ja rasismia, tuloerojen kasvua ja yhteiskunnan resurssien epäoikeudenmukaista jakautumista sekä ympäristön saastumista ja pakolaistilannetta. Työpajan jälkeen tekstiilitaideteokset kiersivät näyttelynä ympäri Suomea. Näyttelyn tavoite oli herätellä ja osallistaa myös katsojia.

Osallistujilta kerättiin kirjallista palautetta heti työpajan jälkeen erillisellä lomakkeella. Lisäksi heille lähetettiin noin vuosi työpajan jälkeen toinen kyselylomake, jolla pyrittiin selvittämään motiiveja kurssille osallistumiseen sekä kokemuksia ja ajatuksia käsityöaktivismista toimintamuotona.

Joillekin työpajaan osallistuneille käsityöaktivismi oli ennestään tuttu käsite ja itsessään osallistumisen syy. Osallistujia tuli muistakin syistä, esimerkiksi siksi, että työpaja tarjosi mahdollisuuden hyvien materiaalien, tilojen ja välineiden käyttöön. Vaikka käsityöaktivismi ei ollut kaikille tuttua, kaikki osallistujat olivat työpajan jälkeen vaikuttuneita oppimastaan, ja jotkut ovat jatkaneet käsityöaktivismia itsenäisesti.

Yhteistä osallistujille olivat halu vaikuttaa yhteiskunnan epäkohtiin ja kiinnostus käsitöihin. Eräs kertoi, että vaikka työskentely kantaaottavien teosten parissa oli antoisaa, se oli ajoittain myös henkisesti kuormittavaa. Hän koki, että syvälliset keskustelut yhteiskunnan epäkohdista ja maailman tilasta tekijöiden kesken herättivät välillä jopa ahdistusta, kun alkoi miettiä omaa voimattomuuttaan. Silti käsityöaktivismi oli hänestä antoisa työskentelymuoto, jonka virittämän yhteisöllisen keskustelun myötä omat ajatukset kehittyivät. Tekijät oppivat myös toinen toisiltaan uusia asioita ja näkökulmia.

Kun Huuda huovuttamalla -työpajan osallistujilta kysyttiin, mitä käsityöaktivismi heidän mielestään oli, eniten mainintoja saivat yhteiskunnallisen muutoksen tavoittelu, keskustelu yhteiskunnallisista asioista käsitöitä tehdessä ja mielipiteen ilmaisu itselle tärkeässä asiassa. Vastauksissa korostui se, että osallistujien mielestä käsityöaktivismissa tärkeintä oli vaikuttaminen eikä niinkään uusien taitojen oppiminen tai vapaa-ajan viettäminen ja rentoutuminen käsitöiden parissa.

Kun osallistujia pyydettiin valitsemaan käsityöaktivismia parhaiten kuvaavia adjektiiveja, eniten mainintoja saivat ilmaisut yllätyksellinen, vaikuttava ja hauska. Osallistujat kokivat käsityöaktivismin keskustelevaksi, sosiaaliseksi ja pohdiskelevaksi. Vastausten perusteella osallistujat kokivat käsityöaktivismin uudenlaiseksi, toimivaksi ja yhteisölliseksi toimintamuodoksi. 

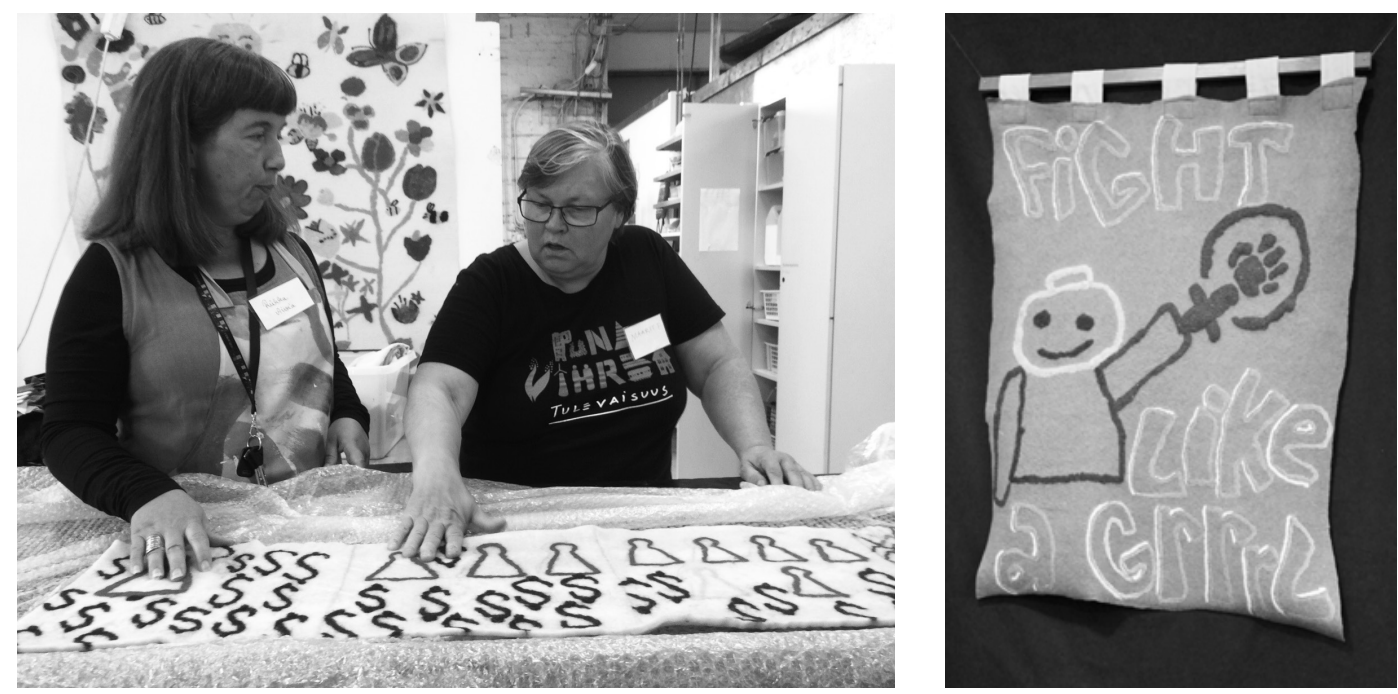

Vas. Maarit Fredlund vasemmassa kuvassa oikealla) otti teoksellaan $1 \%$ - 99 \% kantaa epäoikeudenmukaisiin tuloeroihin. Oik. Linnea Saarits huusi työpajassa tyttöjen oikeuksien puolesta. Kuvat: KSL-opintokeskus.

\section{\#SUOMILUPAUS AKTIVOI KESKUSTELEMAAN}

Huuda huovuttamalla -hanketta laajempi KSLopintokeskuksen järjestämä käsityöaktivismihanke oli vuoden 2017 aikana toteutettu "\#Suomilupaus - aktiiviset kansalaiset luomassa Suomen hyvää tulevaisuutta”. Ajatuksena oli juhlistaa itsenäisyyden 100-vuotisjuhlavuotta luomalla valoisia tulevaisuudenkuvia Suomelle virittämällä ihmisten ajatuksia siihen, kuinka he itse voivat vaikuttaa maan hyvään tulevaisuuteen. Hankevuoden aikana järjestettiin useita \#Suomilupaus-työpajoja tapahtumissa, kuten Maailma kylässä -festivaalilla, Pride Helsingissä, Vasemmistonuorten liittokokouksessa, Nuori ay-vaikuttaja -koulutuksessa ja Suomen kädentaidot -messuilla.

Työpajoissa oli tarjolla neuloja, lankoja ja pahvikortteja, joissa oli valmiiksi painettuna teksti ”Jotta Suomi on hyvä maa kaikille, lupaan..." sekä tyhjää tilaa osallistujan omaa lupausta varten. Työpajalaisia pyydettiin kirjomaan pahviin oma lupauksensa paremman Suomen puolesta.

Hankkeessa pyrittiin tuottamaan mahdollisimman matalan kynnyksen käsityöaktivismia. Kirjonta pahvi- kortille on yksinkertainen menetelmä, jota useimmat ihmiset pystyvät toteuttamaan, ja siksi sopiva työpajaan. Pajojen ohjaajat virittivät yhteiskunnallista keskustelua osallistujien kanssa samalla kun lupauksia ideoitiin ja kirjottiin kortteihin. Käsityöaktivismin kannalta oleellista oli, että ohjaajat pyrkivät saamaan pajalaiset keskustelemaan hyvän tulevaisuuden teemoista myös keskenään. Lopuksi kirjotut lupaukset kuvattiin, ja kuvia jaettiin sosiaalisen median kanavissa Facebookissa ja Instagramissa \#suomilupaustunnisteella.

\#Suomilupaus-työpajoissa ihmiset kirjoivat mittakaavaltaan niin pieniä kuin suuriakin lupauksia paremman Suomen puolesta. He lupasivat puolustaa heikompiosaisia, olla tasa-arvoisia, kierrättää jätteitä sekä kuunnella ja kunnioittaa muita ihmisiä. Jotkin lupaukset, kuten lupaukset läsnäolosta, rakastamisesta ja nauramisesta, olivat hyvin henkilökohtaisia. Pajatilojen seinille ripustettiin valmiita töitä, joita satunnaiset ohikulkijat saattoivat pysähtyä katsomaan. Siten heidätkin pyrittiin osallistamaan.

\#Suomilupaus-työpajoja järjestettiin keskenään hyvin erilaisissa tapahtumissa, mikä osaltaan vaikutti 


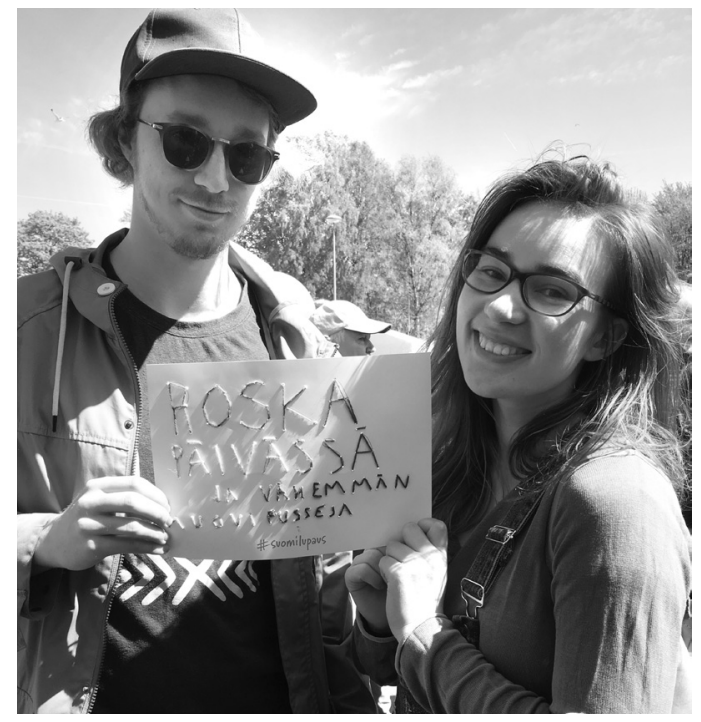

Maailma kylässä -kaupunkifestivaalin kävijä kirjoivat pahville lupauksia paremman Suomen puolesta. Kuva: KSL-opintokeskus.

lupausten sisältöön. Vasemmistonuorten liittokokouksessa ja nuorten ammattiyhdistysvaikuttajien koulutustilaisuudessa syntyneet lupaukset olivat radikaalimpia kuin käsityömessuilla kirjotut lupaukset. Nuoret vaikuttajat lupasivat muun muassa agitoida, opettaa ja järjestää.

Pienelle joukolle nuoria ammattiyhdistysvaikuttajia lähetettiin työpajan jälkeen vapaamuotoinen kysely, jossa heitä pyydettiin kuvailemaan omin sanoin, millaisena toimintamuotona he kokivat käsityöaktivismin. Yhteiskunnallisesti aktiiviset nuoret kokivat, että käsityöaktivismi on raikas ja piristävä vaihtoehto perinteisen aktivismin rinnalle. Heidän mielestään uudenlaisessa aktivismin muodossa parasta on se, että sen avulla voidaan saada yhteiskunnalliseen keskusteluun mukaan myös sellaisia ihmisiä, jotka muuten eivät siihen osallistuisi.

Katsojanäkökulmaa käsityöaktivismiin KSL-opintokeskuksessa haettiin haastattelemalla ja kuuntelemalla käsityöteosten katsojia Tampereella järjestetyillä Suomen Kädentaidot -messuilla. \#Suomilupaus-pajan ohi kulkeneita ihmisiä pyydettiin kertomaan, millaisia ajatuksia pahvikortille kirjotut lupaukset heissä herättivät.
Aluksi kirjotut ja kantaaottavat kortit herättivät ihmisissä lähinnä ihmetystä ja hämmennystä, eikä käsityöaktivismi ollut monellekaan tuttu toimintamuoto. Kun ohikulkijoille kerrottiin, mitä käsityöaktivismi ja \#Suomilupaus-hanke tarkoittivat, useimmat ihastelivat hienoa ideaa ja kokivat sen herättävän pääosin myönteisiä ajatuksia. Monet jäivät keskittyneinä lukemaan lupauksia. Esimerkki vahvistaa sen, että käsityöaktivismilla voidaan aidosti herätellä ja synnyttää ajatuksia myös katsojissa. Yksikään ohikulkija ei osoittanut varsinaisesti kielteisiä tunteita käsityöaktivismihanketta kohtaan. Sen sijaan monen kanssa korttien katsominen synnytti keskustelua nyky-yhteiskunnasta ja siitä, mikä Suomessa oli hyvin ja mikä huonosti.

\section{PEHMEÄÄ AKTIVISMIA TARVITAAN YHTEISKUNNASSA}

KSL-opintokeskuksen toteuttamat hankkeet ovat osoittaneet, että käsityöaktivismi on toimiva pedagogisen toiminnan muoto yhteiskunnallisen keskustelun aktivoijana, säröjen synnyttäjänä ja perinteisten toimintamallien kyseenalaistajana. Se on pehmeää aktivismia, jolle voi olla tilausta laajemminkin yhteiskunnassa, kun keskustelut etenkin julkisuudessa ja sosiaalisessa mediassa kärjistyvät helposti epäkunnioittavaksi ja asiattomaksi kiistelyksi. Käsityöaktivismi on maltillisempi väylä niin yhteiskunnalliselle keskustelulle kuin omien ajatusten ilmaisulle.

KSL-opintokeskuksen kokemukset käsityöaktivismista ovat olleet niin myönteisiä, että toimintamuotoa aiotaan jatkaa ja kehittää edelleen kulttuuritoimintana. KSL kannustaa muitakin vapaan sivistystyön toimijoita ottamaan tulevaisuudessa käsityöaktivismin osaksi pedagogista toimintaansa. Neula ja lanka kädessä yhteiskunnallinen keskustelu ja ajatusten aktivointi voi olla samanaikaisesti vakavaa ja hauskaa.

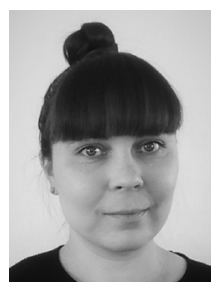

JANITA PERTTULA

KM, käsityönopettaja Käsityö- ja muotoilukoulu Helmi Taito Uusimaa ry

Kansan Sivistystyön Liitto KSL ry rahoittanut näkökulmatekstin kirjoittamista. 
Amnesty. (2017). Bordados por la Paz y la Memoria - Embroideries for Peace and Memory. https:// theamnesty.org/2017/10/11/bordados-por-la-paz$\mathrm{y}$-la-memoria-embroideries-for-peace-and-memory (26.11.2017).

Anttila, P. (1983). Prosessi vai produkti? Tutkimus käsityön asenteista ja arvopäämääristä. Helsinki: Kouluhallitus.

Corbett, S. (2013). A Little Book of Craftivism. IsoBritannia: Clays Ltd.

Corbett, S. (2017). How to Be a Craftivist: the art of gentle protest. Lontoo: Cicada Books Ltd.

DalyGoggin, M. (2014). Threads of Feeling: Embroidering Craftivism to Protest the Disappearances and Deaths in the "War on Drugs" in Mexico. Textile Society of America Symposium Proceedings. 937. http:// digitalcommons.unl.edu/cgi/viewcontent.cgi?article= 1938\&context=tsaconf (25.11.2017).

Designmuseo (2017). Sano se käsin -teosreitti. http:// www.designmuseum.fi/fi/sano-se-kasin-teosreitti (25.11.2017).

Feministinen ajatushautomo Hattu. http://www. hautomohattu.fi/vitun-asiat (25.11.2017).

Giroux, A. \& McLaren, P. (2001). Kriittinen pedagogiikka. Tampere: Vastapaino.

Greer, B. (2014). Craftivism: The Art of Craft and Activism. Vancouver: Arsenal Pulp Press.

Korjaussarjakollektiivi (2017). https://korjaussarjakollektiivi. wordpress.com (25.11.2017).

Kouhia, A. \& Laamanen, T.-K. (2014). Mitä muuta kuin materiaa? Otteita käsityön materiaalisuudesta ja immateriaalisuudesta. Teoksessa Karppinen, S. Kouhia, A. \& Syrjäläinen, E. (toim.). Kättä pidempää. Otteita käsityön tutkimuksesta ja käsitteellistämisestä. Helsinki: Helsingin yliopisto, 11-22.

Martin, B. (2007). Activism, social and political. Teoksessa Anderson, G. \& Herr, K. (toim.). Encyclopedia of Activism and Social Justice. Thousand Oaks, CA: Sage. http://www.bmartin.cc/pubs/07Anderson.html, 19-27.

Niemelä, S. (2011). Sivistyminen. Sivistystarve, -pedagogiikka, ja -politiikka pohjoismaisessa kansansivistystraditiossa. Keuruu:

Kansanvalistusseura.

Ollila, A. (1993). Suomen kotien päivä valkenee... Marttajärjestö suomalaisessa yhteiskunnassa vuoteen 1939. Helsinki: Suomen Historiallinen Seura.

Piesanen, A. (2010). Käsityö ja aktivismi. Käsityö kansalaisaktivismin toimintamuotona 1800-ja 1900-lukujen vaihteen Suomessa. Käsityötieteen pro gradu -tutkielma. Opettajankoulutuslaitos. Helsingin yliopisto.

Suojanen, U. (1993). Käsityökasvatuksen perusteet. Porvoo: WSOY.

The AIDS Memorial Quilt. (2017). The AIDS Memorial Quit. http://www.aidsquilt.org (25.11.2017).

Utopia Helsinki. (2017). Radikaalit ristipistot. https:// utopiahelsinki.wordpress.com/2016/12/18/radikaalit (26.11.2017).

Venkula, J. (2003). Taiteen välttämättömyydestä. Jyväskylä: Kirjapaja. 